\title{
Tree-based Water Footprint Assessment on Established Oil Palm Plantation in North Sumatera, Indonesia
}

\author{
Kajian Jejak Air Berdasarkan Populasi Tegakan pada \\ Perkebunan Kelapa Sawit di Sumatera Utara, Indonesia
}

\author{
Edi Santosa $^{1 *}$, Indra Mario Stefano ${ }^{1}$, Abdul Gani Tarigan ${ }^{2}$, Ade Wachjar $^{1}$, Sofyan Zaman $^{1}$, and Herdhata Agusta ${ }^{1}$
}

${ }^{1}$ Faculty of Agriculture, Bogor Agricultural University. Bogor 16680 Indonesia

${ }^{2}$ Afdeling IV Dolok Ilir Estate, PT Perkebunan Nusantara IV, Medan, Indonesia

Received 13 January 2017/Accepted 5 October 2017

\begin{abstract}
In a long life cycle of oil palm plantation, sustainable water management is mandatory because irrigation is rarely applied. In order to develop water management for sustainable palm oil production, tree-based water footprint of wellestablished oil palm plantation was assessed. Field data were collected from February to June 2016 in Dolok Ilir managed by PTPN IV, North Sumatera, Indonesia. Additional data were obtained from interviews on the site and the surrounding estates, reports and references. Results showed that water footprint (WF) for production of fresh fruit bunch (FFB) was $510.69 \mathrm{~m}^{3}$ tonne ${ }^{-1}$ and crude palm oil (CPO) was $517.79 \mathrm{~m}^{3}$ tonne $\mathrm{e}^{-1}$. Green, blue and grey water contributed $94.78 \%, 0.71 \%$ and $4.50 \%$ in FFB, and $93.48 \%, 1.66 \%$ and $4.85 \%$ in CPO productions, respectively. All green WF was calculated basen on actual value of tree evapotranspiration, therefore, the value was mostly lower than other researchs. Low amount of blue water indicates that the oil palm tree in North Sumatera extracts low amount of ground water. On the other hand, grey water for pollution dilution of fertilizers, pesticides and herbicides were high, i.e., $15.15 \mathrm{~m}^{3}, 4.77 \mathrm{~m}^{3}, 3.07 \mathrm{~m}^{3}$ tonne ${ }^{-1} \mathrm{FFB}$, respectively. It implies that reduction of grey water should be implemented in the near future through precission farming.
\end{abstract}

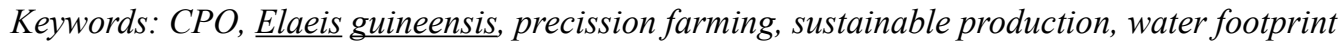

\section{ABSTRAK}

Tanaman kelapa sawit memiliki daur hidup yang panjang sehingga manajemen sumberdaya air menjadi penting untuk menjamin keberlanjutan usaha. Namun, kajian hal tersebut di Indonesia masih terbatas. Penelitian bertujuan mengevaluasi jejak air di perkebunan kelapa sawit yang sudah mapan berdasarkan populasi tegakan dalam rangka mengembangkan manajemen sumberdaya air berkelanjutan. Data dikumpulkan pada Februari-Juni 2016 di Kebun Dolok Ilir PTPN IV, Sumatera Utara, Indonesia. Data tambahan diperoleh dari wawancara, laporan dan pustaka. Nilai jejak air untuk memproduksi tandan buah segar (TBS) adalah $510.69 \mathrm{~m}^{3}$ ton $^{-1}$ dan memproduksi minyak sawit (CPO) adalah $517.79 \mathrm{~m}^{3}$ ton $^{-1}$. Jejak air hijau, biru dan abu-abu berturut-turut menyumbang $94.78 \%, 0.71 \%$ dan $4.50 \%$ pada total jejak air pada produksi TBS, dan $93.48 \%, 1.66 \%$ dan 4.85\% pada produksi CPO. Sehingga, jejak air hijau merupakan komponen terbesar pada produksi TBS dan CPO. Dibandingkan penelitian lain, nilai jejak air hijau tersebut lebih rendah, diduga karena dihitung berdasarkan evapotranspirasi populasi aktual. Jejak air biru termasuk rendah, yang menunjukkan bahwa tanaman kelapa sawit menggunakan sedikit air tanah. Perlu ada upaya khusus mengurangi jejak air abu-abu berasal dari pupuk, pestisida dan herbisida yang besarnya $15.15 \mathrm{~m}^{3}, 4.77 \mathrm{~m}^{3}, 3.07 \mathrm{~m}^{3}$ ton $^{-1} \mathrm{TBS}$; diantaranya melalui penerapan teknik budidaya presisi.

Kata kunci: CPO, Elaeis guineensis, jejak air, budidaya presisi, produksi berkelanjutan

\section{INTRODUCTION}

Global area for oil palm (Elaeis guineensis Jacq.) production has increased markedly from 10 to 17 million ha over the last decade; and the fields predominantly located in

* Penulis untuk korespondensi. e-mail: edisang@gmail.com tropical countries as a home of the rest of tropical rainforest, water sanctuary, biodiversity and carbon reserved (Pirker et al., 2016; Srinivas and Koh, 2016). Therefore, water, pollution and genetic biodiversity managements of large plantation such as oil palm plantation become global concern (Moreno-Peñaranda et al., 2015; Siregar et al., 2015; Saswattecha et al., 2016). 
By 2016, oil palm field in Indonesia covered area of 11.4 million ha comprised of 5.9 million ha operated by private, 4.7 million ha by small holders and 0.8 million ha by state own companies, with annual crude palm oil (CPO) production of 17.4, 11.3 and 2.2 million metric ton, respectively (Dirjenbun, 2016). Thus, it is important to evaluate water utilization by oil palm plantations in Indonesia as a global leader on oil palm production.

Some studies show that oil palm field conserves less nutrients and water than other tree fields (Taufiq et al., 2013; Guillaume et al., 2016; Tarigan et al., 2016). According to Taufiq et al. (2013), discharge water to river by oil palm field is 30 to $40 \%$ lower than that of forest condition. Thus, issues on local water quality and related problem arises inline with increasing size of the palm plantations (Larsen et al., 2014; Euler et al., 2016; Merten et al., 2016). However, water issues from oil palm plantation is not simply evaluated due to complex interaction of edaphic, climatic and agronomic practices (Hoekstra and Chapagain, 2007).

Water footprint (WF) is one of rigorous method to evaluate water utilization by crops (Hoekstra and Chapagain, 2007). In this contex, water used by crop is simplified as virtual water relative total yield that is applicable to all crops (Aivazidou et al., 2016; Lovarelli et al., 2016). Many WF assesments have been made on the oil palm (Bulsink et al., 2009; Mekonnen and Hoekstra, 2011; Zulkifli et al., 2014; Suttayakul et al., 2016) that mostly used field basis calculation. WF evaluation based on tree stand was limited. Tree-based WF needs to be evaluated because WF value is sensitive to volume of water consumption, climate and agricultural practice (Hoekstra and Chapagain, 2007), productivity and region (Bulsink et al., 2009), variety and efficiency on oil extraction (Suttayakul et al., 2016).

Sumatera is home of well-established oil palm plantations in Indonesia. It contributes about $64 \%$ on basis of area or $69 \%$ on basis of the crude oil in the country in which North Sumatera manages area more than one million hectares (Dirjenbun, 2016). Therefore, the objective in the study was to assess water footprint in well-established oil palm plantation in North Sumatera in order to develop better water management.

\section{MATERIALS AND METHODS}

\section{Study Site}

Research was conducted on PTPN IV North Sumatera (125 $\mathrm{m}$ above sea level), Indonesia from February to June 2016. Immature (TBM) and mature trees $(T M)$, and milling factory were assessed in Dolok Ilir Estate, while nursery was at Bah Jambi Estate. The Dolok Ilir Estate had podzolic soil (typic hapludult), and topography mostly flat (82\%). Rainfall ranged from 1,570 to $2,416 \mathrm{~mm}$ (average 1,940 $\mathrm{mm}$ ). The estate dedicated 557 ha for $T B M$ and 5864 ha for $T M$ and 928 ha for other facilities. Plant density was 143 tree ha $^{-1}$ of Tenera variety (Dura x Pisifera). Data were gathered from interviews, reports and publications. In case the field data was not available in the field, information was obtained from public institutions such as RSPO (www.rspo.org).

\section{Water Footprint Calculation}

WF in oil palm field $\left(\mathrm{m}^{3}\right.$ water tonne ${ }^{-1}$ fresh fruit bunchs-FBB, $\left.\mathrm{WF}_{\mathrm{FFB}}\right)$ was summarized from nursery $\left(\mathrm{WF}_{\mathrm{N}}\right)$, immature $\left(\mathrm{WF}_{\mathrm{TBM}}\right)$, and mature $\left(\mathrm{WF}_{\mathrm{TM}}\right)$ stages, as follow: $\mathrm{WF}_{\mathrm{FFB}}=\mathrm{WF}_{\mathrm{NP}}+\mathrm{WF}_{\mathrm{TBM}}+\mathrm{WF}_{\mathrm{TM}}$. WF in palm oil milling $\left(\mathrm{m}^{3}\right.$ water tonne $\mathrm{e}^{-1}$ crude palm oil-CPO, $\mathrm{WF}_{\mathrm{OE}}$ ) was calculated based on $\mathrm{CPO}$ extraction. Thus, total $\mathrm{WF} \mathrm{CPO}=\mathrm{WF}_{\mathrm{FFB}}+$ $\mathrm{WF}_{\mathrm{OE}}$.

The water was classified as green, blue and grey water (Hoekstra et al., 2011), $\mathrm{WF}_{\mathrm{CPO}}=\mathrm{WF}_{\text {green }}+\mathrm{WF}_{\text {blue }}+\mathrm{WF}_{\text {grey }}$. The green $\mathrm{WF}_{\mathrm{FFB}}$ referred to the volume of rainwater consumed for FFB production including transpiration of oil palm tree stand, below vegetation and weed-free area, and harvested biomass (Table 1). Green WF was calculated by dividing the green water use $\left(\mathrm{m}^{3} \mathrm{ha}^{-1}\right)$ by the crop yield $\left(Y\right.$, tonne $\left.\mathrm{ha}^{-1}\right)$. Blue WF referred to the volume of surface and ground water consumed including water for irrigation to FFB production, CPO extraction and domestic labor; it was calculated by dividing the blue water use $\left(\mathrm{m}^{3} \mathrm{ha}^{-1}\right)$ by the crop yield $(Y$, tonne $\mathrm{ha}^{-1}$ ). Due to no irrigation was applied in the study site, water for irrigation was setted as zero; thus Blue WF for oil palm was calculated from difference between water of palm consumption and rainfall. Rainfall interception of palm tree was calculated according to Tanjung (2013) for $T B M$ to $T M-3$, and according to Pasaribu et al. (2012) for $T M-4$ to $T M-20$, i.e., $11.6 \%$ and $21.2 \%$, respectively.

Grey WF is volume of freshwater that is required to dilute the load of pollutants based on natural background concentrations and existing ambient water quality standards (Hoekstra et al., 2011; Franke et al., 2013). The grey WF was calculated based on application of agrochemicals rate (tonne $\mathrm{ha}^{-1}$ ) times the leaching-run-off fraction $(\alpha)$ divided by the maximum acceptable concentration (Cmax, tonne $\left.\mathrm{m}^{-3}\right)$ minus the natural concentration (Cnat, tonne $\mathrm{m}^{-3}$ ) and then divided by the crop yield ( $Y$, tonne ha $\left.{ }^{-1}\right) ; \alpha$ for pesticide and herbicide was 0.01 (Franke et al., 2013). Leaching-runoff fraction $(\alpha)$ for $\mathrm{N}, \mathrm{P}, \mathrm{K}, \mathrm{Mg}, \mathrm{Ca}$ and $\mathrm{B}$ were obtained from mature oil palm plantation, i.e., 0.11, 0.03, 0.05, 0.06, 0.05 , and 0.21, respectively (Comte et al., 2012). Cnat was setted as zero. Cmax value was obtained from United State Environmental Protection Agency (US EPA, www.epa. gov), Ong et al. (2009), Franke et al. (2013), Mekonnen and Hoekstra (2015), and Ministry of Health New Zealand (www.health.govt.nz). In case Cmax value differ among reports, the lowest allowable concentration was used.

Direct WF referred to the water that directly involved at FFB production (Table 1) or CPO extraction (Table 2). Indirect WF refers to the water consumption and pollution that indirectly associated with the production of the FFB or CPO extraction. In present study, the indirect water for production of agrochemicals, diesel lifting, and field tools and materials (Halimah et al., 2014) were excluded from WF calculation. 


\section{Limitation of the Study}

WF of seed production was calculated based on assumption that a FFB produced 1,300 high quality seeds. Blue water of cover crop (LCC) seedling was calculated based on assumption that one hectare of oil palm field required 600 seedling bags of Mucuna bracteata; and each LCC seedling consumed $100 \mathrm{~mL}$ daily for 45 days in the nursery.

A two-stage-nursery of oil palm was used, i.e., 3 months in pre-nursery and 9 months in main-nursery with daily watering was $0.3 \mathrm{~L}$ and $2.0 \mathrm{~L}$ per bag, respectively. For one hectare of palm stand, it required 165 plants at pre-nursery and 150 plants at main-nursery by considering abnormal and dead seedlings. Grey water in the nurseries was considered zero. In established plantation like Dolok Ilir, land clearing was none and trees replanting used herbicide injection. WF for land preparation was concluded from 4 weeks field evaporation, $2 \mathrm{~mm}$ per day. Palm life cycle was determined 24 years composed of 1,3 , and 20 years in nurseries, $T B M$ and $T M$, respectively. Average annual FFB production was determined 19.9 tonne $\mathrm{ha}^{-1}$.

Field evapotranspiration rate (ET) followed equation: $\mathrm{PT}+\mathrm{GV}+\mathrm{FW}+\mathrm{DF}$; where PT-palm transpiration, GV-ground vegetation transpiration of LCC and (or) weeds, FWevaporation weed-free area, and DF-evaporation of fronds dumping site, dead inter-row (called gawangan mati). $\mathrm{ET}_{\mathrm{PT}}$ was assumed 0.2 to $1.3 \mathrm{~mm}$ per day dependent on plant age followed the model of Röll et al (2015). It assumed that a palm tree occupied an area of $12.56 \mathrm{~m}^{2}$. In brief, individual tree water consumption $\left(\mathrm{ET}_{\mathrm{PT}}\right)$ were 12.5, 25.0, and 50.0 liter per day for $T B M-1$ to 3 , and $60.0,75.0,82.5,92.5$, 100.0, and 110.0 liter per day for $T M-1$ to 6 . $\mathrm{ET}_{\mathrm{PT}}$ was 125.0 liter per day for TM-7 to 20 . Total PT $=\sum_{n=1}^{20}(E T n \times 365 \times 143)$; value 365 was days in a year and 143 was tree population $\mathrm{ha}^{-1}$. ET gawangan mati that covered $1800 \mathrm{~m}^{2} \mathrm{ha}^{-1}$ was setted zero. ET ground vegetation was estimated from $100 \%$ LCC for TBM to TM-2, 50\% LCC and 50\% Axonopus compressus for TM-3 to TM-4, and $100 \%$ A. compressus for $T M-5$ to $T M-20$. Crop coefficient (Kc) of A. compressus was determined as 0.3 (Connellan, 2013). M. bracteata growth was assumed decline about $50 \%$ at $T M-3$ and fully suppressed in TM-5. Water efficiency of M. bracteata was estimated from legumes (Biederbeck and Bauman, 1994), i.e., $11 \mathrm{~kg} \mathrm{ha}^{-1} \mathrm{~mm}^{-1} ;$ M. bracteata biomass produced half of 11.02 ton dry mass ha-1 (Chee, 2007).

Weed-free areas of circle below trees (piringan, $4 \mathrm{~m}$ in diameter), collecting road (jalan pikul, $1.5 \mathrm{~m}$ x $600 \mathrm{~m}$ ), and fruit collecting point (tempat pengumpulan hasil, $3 \mathrm{~m} \mathrm{x} 4 \mathrm{~m}$ ) were considered. Weed-free circle was maintained in both $T M$ and $T B M$, while jalan pikul and fruit collecting point were exclusive in $T M$ fields. Weed-free area was $1796 \mathrm{~m}^{2}$ $\mathrm{ha}^{-1}$ for TBM and $2708 \mathrm{~m}^{2} \mathrm{ha}^{-1}$ for TM; and the evaporation rate was determined $1,200 \mathrm{~mm}$ per year (Nuryanto and Rizal, 2013).

Labor WF was evaluated based on labor index (ITK) times 365 days per year for 24 years times average water consumption, i.e., $0.1761 \mathrm{~m}^{3}$ per day. ITK considered 839 permanent labor devided by cropped area $(6,421 \mathrm{ha})$ equal to 0.13 . Manhour of seasonal labor was accumulated and devided by eight working hours per day. Labor in factory was 5.25 mandays per hour. Water for public facilities was obtained from installed water meter device.

Water for agrochemical applications were recorded; and water for nutrient dillution was calculated based on active ingredient(s) or nutrient(s). Application rate of pesticide, herbicide and empty fruit bunch (EFB) was obtained from RSPO (www.rspo.org), and rate of fertilizer was from Silitonga (2015). Nutrient content of EFB followed Abdullah and Sulaiman (2013). Nutrient balance of N, P, $\mathrm{K}, \mathrm{Mg}, \mathrm{Ca}$ and $\mathrm{B}$ were calculated based on application rate considering the nutrient-fixed by biomass of tree, ground cover vegetation and FFB (Abdullah and Sulaiman Pahan, 2013; Mekonnen and Hoekstra, 2015; Brueck and Lammel, 2016). Ground cover biomass was calculated based on $A$. compressus and LCC (Chee, 2007; Purwantari et al., 2015) as in transpiration measurement. Nutrients contribution from dry fronds and tree litter were excluded from analysis.

CPO milling factory was generated by biomass utilized water from Bah Bolon River; had capacity 54 tons FFB resulted 12.96 tonne CPO hour ${ }^{-1}$ (oil extraction rate $24 \%$ ). The milling released effluent with $90 \%$ water.

\section{RESULTS AND DISCUSSION}

WF for FFB production was $510.69 \mathrm{~m}^{3}$ tonne $\mathrm{e}^{-1}$ (Table 1), while WF for CPO production was $517.79 \mathrm{~m}^{3}$ tonne ${ }^{-1}$. The WF values were different from those reported by previous authors. WF for FFB production is reported as much as $853 \mathrm{~m}^{3}$ tonne $\mathrm{e}^{-1}$ (Bulsink et al., 2009), 1,063 $\mathrm{m}^{3}$ tonne $^{-1}$ (Suttayakul et al., 2016), and 1,166 $\mathrm{m}^{3}$ tonne $\mathrm{e}^{-1}$ (Zulkufli et al., 2014), while for CPO production is 4,971 $\mathrm{m}^{3}$ tonne $\mathrm{e}^{-1}$ (Mekonnen and Hoekstra, 2011) and 5,083 $\mathrm{m}^{3}$ tonne $^{-1}$ (Suttayakul et al., 2016). According to Mungkalasiri et al. (2015), WF oil palm depends on productivity, climate, management and model used for calculation. Present study shows that WF calculation based on existing tree stand is lower than those by general modelling such as by Bulsink et al. (2009), Mekonnen and Hoekstra (2011), and Suttayakul et al. (2016). Present study demonstrated that WF calculation based on tree stand transpiration, ground vegetation and weed-free area abled to enhance the accuracy on WF estimates.

Direct water foot print contributed $65.99 \%$ and $65.53 \%$ of total WF in FFB and CPO productions, respectively. The indirect water footprint contributed low on FFB and CPO productions (Figure 1). FFB production required direct water $334.68 \mathrm{~m}^{3}$ tonne $\mathrm{e}^{-1}$ and indirect water $176.01 \mathrm{~m}^{3}$ tonne $\mathrm{e}^{-1}$. High WF in CPO production was due to WF from FFB production. CPO extraction consumed direct water of 7.10 $\mathrm{m}^{3}$ tonne $\mathrm{e}^{-1}$ or $1.38 \%$ of total WF (Table 2 ).

In Dolok Ilir milling factory, water quantity for CPO extraction has complied with goverment regulation, i.e., 1.2 to $1.5 \mathrm{~m}^{3}$ tonne $\mathrm{e}^{-1} \mathrm{FFB}$. Based on water meter record, average water consumption was $1.29 \mathrm{~m}^{3}$ tonne $\mathrm{e}^{-1} \mathrm{FFB}$, at which $1.16 \mathrm{~m}^{3}$ for FFB milling and $0.13 \mathrm{~m}^{3}$ for cleaning factory. Milling factory operated 1 unit boiler, 3 units screw press, 5 units sludge separator, and 1 unit hydrocyclone, equal to 
Table 1. Direct and indirect water footprint $\left(\mathrm{WF}, \mathrm{m}^{3}\right)$ per one tonne fresh fruit bunchs (FFB) of oil palm in Dolok Ilir estate, North Sumatera

\begin{tabular}{|c|c|c|c|c|c|c|}
\hline \multirow{2}{*}{ Component of water usaged } & \multicolumn{3}{|c|}{ Direct WF $\left(\mathrm{m}^{3}\right.$ tonne $\left.{ }^{-1}\right)$} & \multicolumn{3}{|c|}{ Indirect WF $\left(\mathrm{m}^{3}\right.$ tonne $\left.{ }^{-1}\right)$} \\
\hline & Green & Blue & Grey & Green & Blue & Grey \\
\hline Labor on seedling and mature & - & - & - & - & 0.89 & - \\
\hline Seed production & - & - & - & 0.001 & - & - \\
\hline Seedling legume & - & - & - & 0.01 & - & - \\
\hline Land preparation & - & - & - & 1.52 & - & - \\
\hline Transpiration oil palm & 309.17 & 2.01 & - & - & - & - \\
\hline Transpiration ground vegetation & - & - & - & 132.89 & - & - \\
\hline Evaporation weed-free area & - & - & - & 18.46 & - & - \\
\hline Rainfall interception & - & - & - & 21.71 & - & - \\
\hline Irigation water in nursery & - & 0.20 & - & - & - & - \\
\hline Agrochemicals application & 0.03 & - & - & - & - & - \\
\hline Pesticides assimilation & - & - & 4.77 & - & - & - \\
\hline Herbicides assimilation & - & - & 3.07 & - & - & - \\
\hline Fertilizers assimilation & - & - & 15.15 & - & - & - \\
\hline Total biomass oil palm & 0.28 & - & - & - & - & - \\
\hline Biomass ground vegetation & - & - & - & 0.27 & - & - \\
\hline Public facilites & - & - & - & - & 0.55 & - \\
\hline Total & 309.48 & 2.31 & 22.99 & 174.86 & 1.44 & 0 \\
\hline
\end{tabular}

' - 'denotes no value

water consumption of $35.0,30.0,17.5$ and $0.5 \mathrm{~m}^{3}$ hour ${ }^{-1}$, respectively.

FFB production consumed $484.05 \mathrm{~m}^{3}$ green $\mathrm{WF}, 3.65$ $\mathrm{m}^{3}$ blue $\mathrm{WF}$ and $22.99 \mathrm{~m}^{3}$ grey WF equal to $94.78 \%, 0.71 \%$ and $4.52 \%$, respectively (Figure 2). Suttayakul et al. (2016) stated that green, blue, and grey waters contributes $68 \%$,

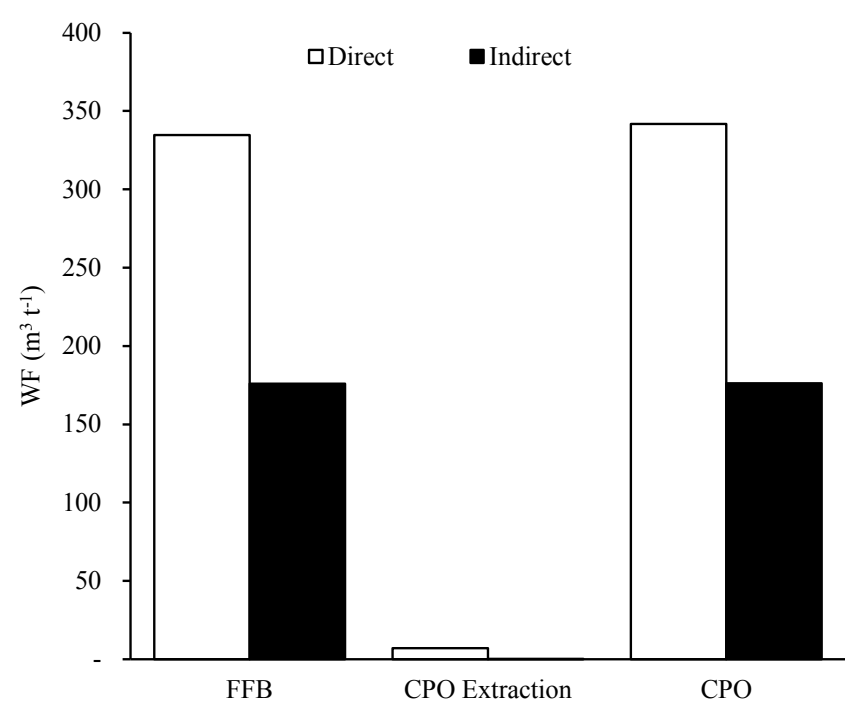

Figure 1. Direct and indirect water footprint $(\mathrm{WF})$ of fresh fruit bunchs production (FFB), crude palm oil extraction (CPO Extraction) and CPO production (CPO) in Dolok Ilir Estate, North Sumatera
$18 \%$, and $14 \%$ to total WF, respectively. High value of green water indicates that the site is suitable for oil palm production in water perspective. Every year, there is a month between February and June with rainfall less than 60 $\mathrm{mm}$. During particular period, oil palm trees utilized ground water (blue WF) for growing. Low blue water requirement in present study than that in Thailand (Suttayakul et al., 2016), indicates that oil palm production in North Sumatera is more sustain on reference to ground water conservation.

No green water was used for CPO extraction (Figure 2). Oil extraction utilized blue water for milling at rate 4.86 $\mathrm{m}^{3}$ tonne $\mathrm{e}^{-1} \mathrm{CPO}$ and $0.54 \mathrm{~m}^{3}$ tonne $\mathrm{e}^{-1} \mathrm{CPO}$ for cleaning factory (Table 2). Thirty percent of WF in CPO extraction was grey water from milling effluent. It needs further evaluation on $\mathrm{CPO}$ extraction because grey water from water treatment, water coolant, electric generation and milling effluent that sink to waterbody had not incorporated yet in present study. High proportion of blue water at milling factory, resulted in higher blue WF of CPO production (Figure 2).

Grey WF in FFB production of present study is lower than study in Malaysia by Zulkifli et al. (2014), although the annual FFB production is nearly equal, i.e., 20.7 tonne ha-1 in Malaysia vs. 19.9 tonne ha- ${ }^{-1}$ in North Sumatera. Out of $22.99 \mathrm{~m}^{3}$ grey WF in every tonne of FFB production, $65.90 \%$ was used to assimilate fertilizers, $20.75 \%$ to assimilate pesticides and $13.35 \%$ to assimilate herbicides. Large amount of water was used for assimilating magnesium and boron, i.e., $46.44 \%$ and $22.89 \%$, respectively, followed by nitrogen $(14.16 \%)$, calcium $(10.38 \%)$, phosphorus $(4.64 \%)$, 
Table 2. Direct and indirect water footprint $\left(\mathrm{WF}, \mathrm{m}^{3}\right)$ per one tonne crude palm oil (CPO) extraction in Dolok Ilir milling factory, North Sumatera

\begin{tabular}{|c|c|c|c|c|c|c|}
\hline \multirow{2}{*}{ Water usaged } & \multicolumn{3}{|c|}{ Direct WF $\left(\mathrm{m}^{3}\right.$ tonne $\left.{ }^{-1}\right)$} & \multicolumn{3}{|c|}{ Indirect WF $\left(\mathrm{m}^{3}\right.$ tonne $\left.\mathrm{e}^{-1}\right)$} \\
\hline & Green & Blue & Grey & Green & Blue & Grey \\
\hline Labor & - & - & - & - & 0.01 & - \\
\hline Milling factory & - & 4.9 & - & - & - & - \\
\hline Effluent & - & - & 2.13 & - & - & - \\
\hline Total & 0 & 4.9 & 2.13 & 0 & 0.01 & 0 \\
\hline
\end{tabular}

'- ' denotes no value

and potassium (1.08\%) (Figure 3A). Water for assimilating herbicides was $3.07 \mathrm{~m}^{3}$ tonne ${ }^{-1} \mathrm{FFB}$, at which $67.80 \% \mathrm{WF}$ was used for assimilating paraquate dichloride, followed by fluroxypyr (16.38\%), isoprophylamina glyphosate (14.60\%), and metil metsulfuron (1.23\%) (Figure 3B). Water to assimilate pesticide was $4.77 \mathrm{~m}^{3}$ tonne $\mathrm{e}^{-1} \mathrm{FFB}$ at which $54.79 \%$ WF was used for assimilating acephate, followed by deltametrine $(40.81 \%)$, dimehypo $(2.11 \%)$, carbosulfan ( $1.51 \%)$, and cypermethrine $(0.79 \%)$ (Figure $3 \mathrm{C})$.

Grey WF is determined by management of fertilizers, pesticide and herbicides (Franke et al., 2013). High grey WF for agrochemicals dilution might be one of indications of luxury application. Based on calculation, excess of nitrogen in the form of amonium or nitrite, irrespectively, was at rate of $12.39 \mathrm{~g}$ per day followed by potassium at rate of 7.62 $\mathrm{g}$ per day and boron at rate of $6.88 \mathrm{~g} \mathrm{day}^{-1}$. High annual $\mathrm{N}$ and $\mathrm{K}$ fluxes to waterbody has been noted by Comte et al. (2012) in Jambi plantation at rate 1.53 to $8.24 \mathrm{~kg} \mathrm{NO}_{3}-\mathrm{N} \mathrm{ha}^{-1}$ and 5.4 to $37.9 \mathrm{~kg} \mathrm{~K}^{+} \mathrm{ha}^{-1}$, respectively.

The palm oil industry is a major water polluter in Southeast Asia because uses large amounts of fertilizers (Muyibi et al., 2008), and discharge POME (Wu et al.,

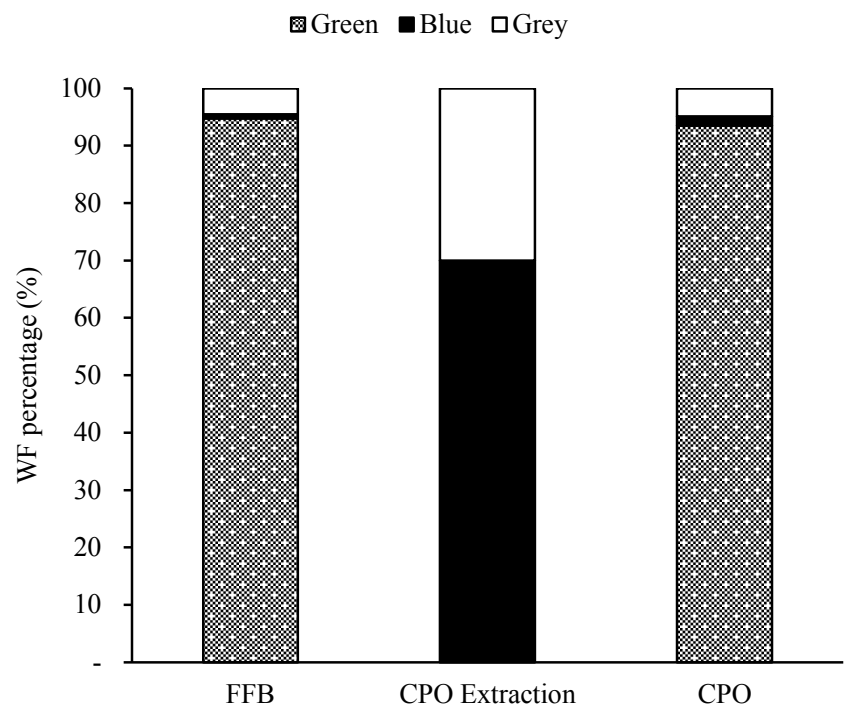

Figure 2. Proportion of green, blue and grey water footprint (WF) of fresh fruit bunchs production (FFB), crude palm oil extraction (CPO Extraction) and CPO production (CPO) in Dolok Ilir Estate, North Sumatera
2010) to aquatic ecosystems; a challenge for Indonesian (de Jong et al., 2015; Comte et al., 2015). According to Saswattecha et al. (2015) five most activities in palm oil field that contribute negative impact onto environmental are: burning fibers in boilers, use of fertilizers, wastewater treatment and empty-fruit-bunch disposal, gasoline in weed cutters and glyphosate for control of weed.

Although in palm field the fertilizer inputs could be different from time to time depend on plantage, environmental issues, price, as well as local regulation (Hoekstra and Chapagain, 2007), to reduce fertilizer application in palm field is not easy. Intensive cultivation could lead to intensive soil degradation under oil palms. According to Guillaume et al. (2016) $10 \%$ of soils under oil palms had very low C content $(<1 \%)$. Thus, field improvement could be made to reduce nutrient leaching. In rubber plantation, Rusli and Heryana (2015) revealed that silt pit (rorak) construction enables to conserve N-P-K nutritions from sinking to waterbody. Furthermore, Tarigan et al. (2016) demonstrated that application of frond pile management, and its combination with silt pit construction reduce run-off water by $10 \%$ and $31 \%$ in palm field, respectively. Utilization of ground cover Nephrolepis biserrata as a cover crop in combination with ridge terracing reduces the rate of water loss by percolation and run-off by $36 \%$ and $80 \%$, respectively according to Ariyanti et al. (2016). Comte et al. (2012) demonstrated that although oil plantation receives high fertilizer application, nutrient losses especially $\mathrm{Mg}^{+}$into the waterbody is equal fluxes from forest if EFB is applied as mulch. These facts exhibite that better field management reduce grey WF in the oil palm field.

In WF evaluation, over or underestimate value might occurs due to agronomic factors such as palm genotype, age, culture techniques and record data availability. In Dolok Ilir, the palm genotypes composed of Marihat, Lonsum and Socfindo. Palupi and Dedywiryanto (2008) stated that oil palm genotype determines water use. Variation in plant density and number of existing frond among plantations was eviden. Number of standing tree reduced by about $37 \%$ at $T M-5$, and by about $50 \%$ at $T M-13$ from original planting 143 plants ha ${ }^{-1}$ in Dolok Ilir due to Ganoderma sp. infection. Overcounting standing crop consequently underestimates coverage of ground cover vegetations and weed-free areas, leading to lower WF values. According to Gromikora et al. 

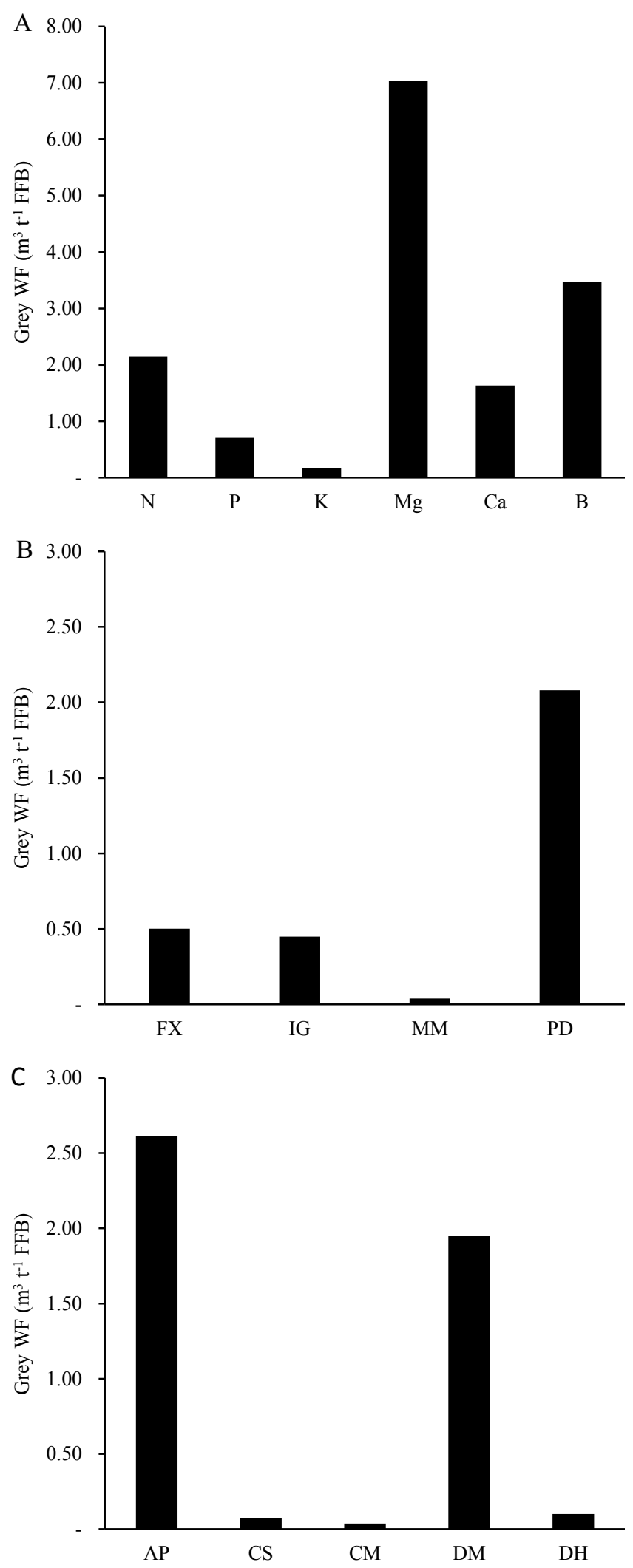

Figure 3. Grey water footprint (WF) of fresh fruit bunch (FFB) production for assimilation of fertilizers (A), herbicides (B) and pesticides (C) in Dolok Ilir Estate, North Sumatera.FX-fluroxypyr,IG-isopropylaminaglyphosate, MM-metil metsulfuron, PD-paraquat dichloride, APacephate, CS-carbosulfan, CM-cypermethrine, DMdeltametrine and DH-dimehypo
(2014), number of existing frond per tree determines level of production. In the field, number of frond per tree ranged from 37 to 52 depend on tree age and fruit load. Moreover, mishandling of herbicide application at rate 15 to $20 \%$ was found during study, causes miscalculation on acreage of weed-free areas.

Recently, adoption of new cover crops such as Mucuna bracteata, Neprolepsis bisserata, and Asystasia $s p$, and some forages crops in palm field is increasing (Prof. Sudirman Yahya, agronomist, personal communication 2016). According to Saswattecha et al. (2016) application of EFB and cover crops as mulch improve oil palm sustainability. According to Ariyanti et al. (2016) planting Nephrolepis biserrata Kuntze as ground cover vegetation of oil palm field improves soil water during dry season. However, application of these new cover crops needs further evaluation especially on its contribution to green and blue WF consumption.

Finally, in advance oil palm management (Afriyanti et al., 2016; Saswattecha et al., 2016), effort to reduce transpiration rate of weed-free area and ground vegetations should be implemented in order to address water and environmental issue (Moreno-Peñaranda et al., 2015). Instead of some difficulties to obtain the accurate climatic and agrochemical data, WF evaluation enable to describe the basic need on water management. In the future, field improvement should be made to alter pollution to waterbody from the agrochemical inputs as indicating by grey WF, such as through implementing precission farming.

\section{CONCLUSION}

Water footprint in oil plantation was $510.69 \mathrm{~m}^{3}$ tonne $^{-1} \mathrm{FFB}$ and $517.79 \mathrm{~m}^{3}$ tonne $^{-1} \mathrm{CPO}$. Every tonne FFB required $484.05 \mathrm{~m}^{3}(94.78 \%), 3.65 \mathrm{~m}^{3}(0.71 \%)$ and $22.99 \mathrm{~m}^{3}$ $(4.50 \%)$ of green, blue and grey WF, respectively. In CPO production, additional blue and grey water on to FFB at rate 8.62 and $25.12 \mathrm{~m}^{3}$ tonne ${ }^{-1}$ or $1.66 \%$ and $4.85 \%$, respectively, was required. Green water in CPO production (93.48\%) mostly derived from FFB production. Large green and grey WF for FFB and CPO production denoted the importance to manage water resources. It implies that precission farming is mandatory in the plantation in order to sustain palm oil production.

\section{ACKNOWLEDGEMENT}

The authors wish to acknowledge PT Perkebunan Nusantara IV for supporting the study and publishing this work.

\section{REFFERENCE}

Abdullah, N., F. Sulaiman. 2013. The properties of the washed empty fruit bunches of oil palm. J. Physical Sci. 24:117-137. 
Afriyanti, A., C. Kroeze, A. Saad. 2016. Indonesia palm oil production without deforestation and peat conversion by 2050. Sci. Total Environ. 557-558:562-570.

Aivazidou, E., N. Tsolakis, E. Iakovou, D. Vlachos. 2016. The emerging role of water footprint in supply chain management: A critical literature synthesis and a hierarchical decision-making framework. J. Cleaner Prod. 137:1018-1037.

Ariyanti, M., S. Yahya, K. Murtilaksono, Suwarto, H.H. Siregar. 2016. Water balance in oil palm plantation with ridge terrace and Nephrolepis biserrata as cover crop. J. Trop. Crop Sci. 3:35-47.

Biederbeck, V.O., O.T. Bauman. 1994. Water use by annual green legumes in dry land cropping system. Agron. J. 86:543-549.

Brueck, H., J. Lammel. 2016. Impact of fertilizer application on the grey water footprint of winter wheat in a NWEuropean temperate climate. Water 8:356.

Bulsink, F., A.Y. Hoekstra, M.J. Booij. 2009. The water footprint of Indonesian provinces related to the consumption of crop products. Value of Water Research ReportSeries No37.UNESCO-IHEInstitute for Water Education, Delfi, The Netherlands.

Chee, K.H. 2007. Mucuna bracteata-a cover crop and living green manure. Agroworld 188:30-34 (In Chinese).

Comte, I., F. Colin, J. K. Whalen, O. Grünberger, J. P. Caliman. 2012. Agricultural practices in oil palm plantations and their impact on hydrological changes, nutrient fluxes and water quality in Indonesia: A review. Adv. Agron. 116:71-124.

Comte, I., F. Colin, O. Grünberger, J.K. Whalen, R.H. Widodo, J.P Caliman. 2015. Watershed-scale assessment of oil palm cultivation impact on water quality and nutrient fluxes: A case study in Sumatra (Indonesia). Environ. Sci. Pollut. Res. 22:76767695 .

Connellan, G. 2013. Water use efficiency for irrigated turf and landscape. CSIRO Publ., Australia.

de Jong, E.B.P., A.M.J. Ragas, G. Nooteboom, M. Mursidi. 2015. Changing water quality in the middle Mahakam lakes: Water quality trends in a context of rapid deforestation, mining and palm oil plantation development in Indonesia's Middle Mahakam Wetlands. Wetlands 35:733-744.

[Dirjenbun] Direktorat Jenderal Perkebunan. 2016. Tree Crop Estate Statistics of Indonesia 2015-2017: Palm
Oil. Directorate General of Estate Crops, Ministry of Agriculture Republic of Indonesia. Jakarta. (In Indonesian).

Euler, M., M.P. Hoffmann, Z. Fathoni, S. Schwarze. 2016. Exploring yield gaps in smallholder oil palm production systems in Eastern Sumatra, Indonesia. Agric. Syst. 146:111-119.

Franke, N.A., H. Boyacioglu, A.Y. Hoekstra. 2013. Grey Water Footprint Accounting: Tier 1 Supporting Guidelines. Value of Water Research Report Series No. 65. UNESCO-IHE Institute for Water Education, Delft, Netherland.

Gromikora, N., S. Yahya, Suwarto. 2014. Growth and production modeling of oil palm at different levels of frond pruning. J. Agron. Indonesia 42:228-235.

Guillaume, T., A.M. Holtkamp, M. Damris, B. Brummer, Y. Kuzyakov. 2016. Soil degradation in oil palm and rubber plantations under land resource scarcity. Agric. Ecosyst. Environ. 232:110-118.

Halimah, M., S. Vijaya, H. Zulkifli, S.K.K. Nik, Y.M. Choo. 2014. Water footprint: Part 1 - Production of oil palm seedlings in Peninsular Malaysia. J. Oil Palm Res. 26:273-281.

Hoekstra, A.Y., A.K. Chapagain, M.M. Aldaya, M.M. Mekonnen. 2011. The Water Footprint Assessment Manual: setting the global standard. Earthscan Ltd, London-Washington DC, UK.

Hoekstra, A.Y., A.K. Chapagain. 2007. Water footprints of nations: water use by people as a function of their consumption pattern. Water Resour. Manag. 21:3548 .

Larsen, R.K., N. Jiwan, A. Rompas, J. Jenito, M. Osbeck, A. Tarigan. 2014. Towards 'hybrid accountability' in EU biofuels policy? Community grievances and competing water claims in the Central Kalimantan oil palm sector. Geoforum 54:295-305.

Lovarelli, D., J. Bacenetti, M. Fiala. 2016. Water footprint of crop productions: A review. Sci. Total Environ. 548-549:236-251.

Mekonnen, M. M., A.Y. Hoekstra. 2011. The green, blue and grey water footprint of crops and derived crop products. Hydrology Earth Syst. Sci. 15:1577-1600.

Mekonnen, M.M., A. Y. Hoekstra. 2015. Global gray water footprint and water pollution levels related to anthropogenic nitrogen loads to fresh water. Environ. Sci. Technol. 49:12860-12868. 
Merten, J., A. Röll, T. Guillaume, A. Meijide, S. Tarigan, H. Agusta, C. Dislich, C. Dittrich, H. Faust, D. Gunawan, J. Hein, Hendrayanto, A. Knohl, Y. Kuzyakov, K. Wiegand, D. Hölscher. 2016. Water scarcity and oil palm expansion: Social views and environmental processes. Ecol. Soc. 21:5.

Moreno-Peñaranda, R., A. Gasparatos, P. Stromberg, A. Suwa, A.H. Pandyaswargo, J.A.P. de Oliveira. 2015. Sustainable production and consumption of palm oil in Indonesia: What can stakeholder perceptions offer to the debate? Sustainable Prod. Consump. 4:16-35.

Mungkalasiri, J., R. Wisansuwannakorn, W. Paengjuntuek. 2015. Water footprint evaluation of oil palm fresh fruit bunches in Pathumthani and Chonburi (Thailand). Internat. J. Environ. Sci. Dev. 6(6):455-459.

Muyibi, S.A., A.R. Ambali, G.S. Eissa. 2008. Developmentinduced water pollution in Malaysia: Policy implications from an econometric analysis. Water Policy 10:193-206.

Nuryanto, D.E., J. Rizal. 2013. Comparison of potential evapotranspiration between output result of RegCM 4.0 model with calculation of observation data. J. Meteor. Geofisika 14:75-85. (In Indonesian).

Ong, C.N., A.C. Grandjean, R.P. Heaney. 2009. The mineral composition of water and its contribution to calcium and magnesium intake. P 36-. In J. Cotruvo and J. Bartram (Eds.). Calcium and Magnesium in drinkingwater. WHO, Spain.

Palupi, E.R., Y. Dedywiryanto. 2008. A study on characteristics related to drought resistance in four genotypes of oil palm (Elaeis guineensis) seedling. Bul. Agron. 36:24-32.

Pasaribu, H., A. Mulyadi, S. Tarumun. 2012. Water balance in oil palm plantation at PPKS unit Kalianta Kabun Riau. J. Ilmu Lingkungan 6:99-113. (In Indonesian).

Pirker, J., A. Mosnier, F. Kraxner, P. Havlík, M. Obersteiner. 2016. What are the limits to oil palm expansion? Global Environ. Change 40:73-81.

Purwantari, N.D., B. Tiesnamurti, Y. Adinata. 2015. Availability of forage under oil palm plantation for cattle grazing. Wartazoa 25:47-54. (In Indonesian).

Röll, A., F. Niu, A. Meijide, A. Hardanto, Hendrayanto, A. Knohl, D. Hölscher. 2015. Transpiration in an oil palm landscape: effects of palm age. Biogeosci. 12:5619-5633.

Rusli, N. Heryana. 2015. Impact and anticipation of drought on rubber plant. Sirinov 3:83-92. (In Indonesian).
Saswattecha, K., C. Kroeze, W. Jawjit, L. Hein. 2015. Assessing the environmental impact of palm oil produced in Thailand. J. Cleaner Prod. 100:150-169.

Saswattecha, K., C. Kroeze, W. Jawjit, L. Hein. 2016. Options to reduce environmental impact of palm oil production in Thailand. J. Cleaner Prod. 137:370-393.

Silitonga, A.R.P. 2015. Fertilization Management of Oil Palm Mature Plant at Adolina Estate, PT Perkebunan Nusantara IV, Serdang Bedagai, North Sumatera. Undergraduate thesis. Institut Pertanian Bogor. Bogor, Indonesia. (In Indonesian).

Siregar, K., A.H. Tambunan, A.K. Irwanto, S.S. Wirawan, T. Araki. 2015. A comparison of life cycle assessment on oil palm (Elaeis guineensis Jacq.) and physic nut (Jatropha curcas Linn.) as feedstock for biodiesel production in Indonesia. Energy Procedia 65:170179.

Srinivas, A., L.P. Koh. 2016. Oil palm expansion drives avifaunal decline in the Pucallpa region of Peruvian Amazonia. Global Ecol. Conserv. 7:183-200.

Suttayakul, P., A.H. Kittikun, C. Suksaroj, J. Mungkalasiri, R. Wisansuwannakorn, C. Musikavong. 2016. Water footprints of products of oil palm plantations and palm oil mills in Thailand. Sci. Total Environ. 542 (Part A):521-529.

Tanjung, A.P., Sumono, L.A. Harahap. 2013. Rainfall analysis in Kebun Rambutan oil palm plantation PT Perkebunan Nusantara III with water balance model. J. Rekayasa Pangan Pertanian 1:83-88. (In Indonesian).

Tarigan, S.D., Sunarti, K. Wiegand, C. Dislich, B. Slamet, J. Heinonen, K. Meyer. 2016. Mitigation options for improving the ecosystem function of water flow regulation in a watershed with rapid expansion of oil palm plantations. Sustain. Water Quality Ecol. Doi:10.1016/j.swaqe.2016.05.001.

Taufiq, M., H. Siswoyo, W.W.S. Anggara. 2013. Effect of oil palm plantation on forest water balance (Case study Subdas Landak, DAS Kapuas). J. Teknik Pengairan 4:47-52. (In Indonesian).

Wu, T.A., A.W. Mohammad, J.M. Jahim, N. Anuar. 2010. Pollution control technologies for the treatment of palm oil mill effluent (POME) through end-of-pipe processes. J. Environ. Manag. 91:1467-1490.

Zulkifli, H., M. Halimah, S. Vijaya, Y.M. Choo. 2014. Water footprint: Part 2- FFB production for oil palm planted in Malaysia. J. Oil Palm Res. 26:282-291. 